\title{
PENGARUH HUBUNGAN INTERPERSONAL TERHADAP MOTIVASI BERPRESTASI PADA MAHASISWA PBSI STKIP BUDIDAYA BINJAI STAMBUK 2017/2018
}

\author{
Ayu Mayyasya Yusuf ${ }^{1}$ Nurul Hasanah, M.Si \\ Program Studi Bimbingan dan Konseling \\ STKIP Budidaya Binjai
}

\begin{abstract}
Abstrak
Motivasi berprestasi ialah dorongan dari dalam diri untuk mengatasi segala tantangan dan hambatan dalam upaya mencapai tujuan. Interpersonal secara umum adalah proses komunikasi yang berlangsung antara dua orang atau lebih secara tatap muka. Penelitian ini bertujuan untuk mengetahui pengaruh hubungan interpersonal terhadap motivasi berprestasi pada mahasiswa stkip budidaya binjai stambuk 2017/2018. Metode penelitian yang digunakan dalam penelitian ini merupakan jenis penelitian kuantitatif dengan metode korelasional. Penelitian ini menggunakan uji hipotesis. Populasi dalam penelitian ini adalah mahasiswa PBSI stambuk 2017/2018yang berjumlah 60 orang. Sampel yang diambil adalah keseluruhan dari populasi yaitu sebanyak 60 orang mahasiswa dari total keseluruhan populasi. Penelitian ini dilaksanakan di STKIP Budidaya Binjai. nilai variabel hubungan interpersonal terdistribusi secara normal dengan nilai $\mathrm{p}>0,05$ $(0,061>0,05)$. Dan nilai variabel religiusitas terdistribusi secara normal dengan nilai $\mathrm{P}>0,05(0,372>$ 0,05). Berdasarkan hasil penelitian yang telah dilakukan, maka dapat disimpulkan bahwa ada pengaruh hubungan interpersonal terhadap motivasi berprestasi pada mahasiswa PBSI, hal ini dibuktikan dengan, hal ini dibuktikan dengan nilai hasil koefisien korelasi yang menunjukan angka 0,330 dengan nilai sig 0,005 dimana $p<0,05$. Artinya semakin tinggi hubungan interpersonal maka semakin baik motivasi berprestasi pada mahasiswa tersebut. Sebaliknya, semakin rendah hubungan interpersonal maka motivasi berprestasi pada mahasiswa semakin rendah.
\end{abstract}

\section{Kata Kunci : Hubungan Interpersonal, Motivasi Berprestasi}

\section{PENDAHULUAN}

\section{Latar Belakang Masalah}

Hubungan interpersonal adalah kemampuan memahami pikiran, sikap, dan perilaku orang lain. Sikap-sikap yang ditunjukkan oleh anak dalam hubungan interpersonal sangat menyejukkan dan penuh kedamaian. Oleh karena itu, hubungan interpersonal dapat didefinisikan "motivasi dan keinginan orang lain, serta kemampuan memberikan respons secara tepat terhadap suasana hati, temperamen, motivasi dan keinginan orang lain sebagai kemampuan mempersepsi dan membedakan suasana hati, serta kemampuan memberikan respons secara tepat terhadap suasana hati, temperamen, motivasi dan keinginan orang lain".
Pada proses pembelajaran berlangsung mahasiswa mengalami masalah komunikasi baik dengan dosen maupun dengan temannya sendiri, dimana mahasiswa tersebut punya hubungan interpersonal dan berkaitan dengan hasil belajarnya. Mahasiswa kadang malu dan takut bertanya kepada dosen tentang pelajaran yang tidak dimengertinya. Demikian pula semenjak manusia saling bergaul, terhadap usaha-usaha dari orang-orang yang lebih mampu dalam hal tertentu untuk mempengaruhi orang-orang lain teman bergaul mereka, untuk kepentingan kemajuan orang-orang bersangkutan itu. Salah satu kemampuan interpersonal adalah kemampuan berkomunikasi. Komunikasi merupakan kegiatan yang sangat penting dalam berorganisasi. Menurut Rahkmat, mengatakan bahwa "komunikasi merupakan suatu proses yang berkembang yaitu bersifat impersonal menjadi 
interpersonal, artinya adanya peningkatan hubungan di antara pelaku komunikasi, seringkali pertemuan interpersonal diawali dengan pembicaraan pada masalahmasalah yang bersifat umum, seperti umur, tempat tinggal, pendidikan asal daerah dan sebagainya". Pada akhirnya pembicaraan tersebut berkembang pada masalahmasalah yang spesifik, seperti kebiasaan, kesukaan, situasi tersebut menunjukan adanya komunikasi interpersonal. Komunikasi pada prinsipnya dilakukan untuk menemukan konsesus sebagai winwin solution pada berbagai permasalahan.

Menurut Siagian, "motivasi adalah daya pendorong yang mengakibatkan seorang anggota organisasi mau dan rela untuk mengerahkan kemampuan dalam bentuk keahlian atauketerampilan, tenaga dan waktunya untuk menyelenggarakan berbagai kegiatan yang menjadi tanggung jawabnya dan menunaikan kewajibannya dalam rangka pencapaian tujuan dan berbagai sasaran organisasi yang telah ditentukan sebelumnya".

Mahasiswa merupakan setiap orang yang secara resmi telah terdaftar untuk mengikuti pelajaran di perguruan tinggi dengan batas usia sekitar antara 18 - 30 tahun. Mahasiswa adalah suatu kelompok dalam masyarakat yang memperoleh status karena memiliki ikatan dengan perguruan tinggi. Mahasiswa juga merupakan seorang calon intelektual ataupun cendekiawan muda dalam suatu lapisan masyarakat yang sering kali syarat dengan berbagai predikat dalam masyarakat itu sendiri. Sebagai seorang mahasiswa tentu sangatlah penting bagi dirinya untuk memiliki interpersonal yang baik khususnya dalam berkomunikasi dan sangatlah penting memiliki motivasi dalam dirinya untuk terus berprestasi.

Pada mahasiswa di STKIP Budidaya Binjai ternyata masih ada yang memiliki motivasi berprestasi yang rendah, dikarenakan dari faktor lingkungan, teman terdekat, malas belajar, tidak hadir kuliah dengan alasan yang tidak jelas, main telepon seluler didalam kelas, tidak memperhatikan dan bahkan mahasiswa sering bicara sendiri dengan temannya sehingga membuat gaduh atau ramai, dan kurangnya konsentrasi dosen dalam mata kuliah sehingga mahasiswa merasakan kurang terobsesi menerima apa yang di sampaikan oleh dosen tersebut.

Berdasarkan uraian di atas, maka idealnya semua mahasiswa harus memilki motivasi berprestasi yang tinggi. Penanaman motivasi berprestasi bagi mahasiswa bukti menunjukan bahwa terdapat keinginan untuk mencapai prestasi sesuai dengan standard kampus yang telah ditetapkan. Motivasi berprestasi yang ditanamkan pada diri setiap mahasiswa memberikan andil yang cukup besaruntuk meraih hasil belajar/prestasi secara optimal.

Latar belakang masalah yang sebagaimana telah penulis kemukakan diatas dan juga dalam upaya membantu mahasiswa dalam mengatasi masalahnya secara positif. Bila kita lihat dalam proses belajar mengajar. Siswa yang memiliki motivasi yang tinggi dalam belajar akan melakukan kegiatan lebih cepat dibandingkan dengansiswa yang kurang termotivasidalam belajar. Siswa yang yang memiliki motivasi yang tinggi dalam belajar maka prestasi yang diraih juga akan lebih baik. Maka peneliti tertarik untuk melaksanakan penelitian ini dengan judul "Pengaruh Hubungan Interpersonal Terhadap Motivasi Berprestasi Pada Mahasiswa PBSI STKIP Budidaya Binjai Stambuk 2017/2018".

\section{Identifikasi Masalah}

Berdasarkan latar belakang tersebut, maka permasalahan yang diteliti dari penelitian ini adalah

1. Adanya beberapa mahasiswa yang prestasi belajarnya rendah disebabkan karena ketidakdisiplinan mahasiswa dalam belajar.

2. Prestasi belajar mahasiswa yang rendah disebabkan karena kurangnya kompetensi dosen dalam mengajar.

3. Masih ada beberapa mahasiswa - mahasiswi merasakan tingkat kejenuhan ini dalam mengikuti perkuliahannya.

\section{METODE PENELITIAN}

Penelitian ini dilaksanakan di STKIP Budidaya Binjai yang berlamat di Jl. Gaharu No. 147 Kelurahan Jati Makmur Kota Binjai. Penelitian ini adalah penelitian kuantitatif. Alat ukur motivasi berprestasi berupa angket. populasi dalam penelitian ini adalah keseluruhan mahasiswa PBSID tingkat awal di STKIP Budidaya Binjai yang berjumlah 61 Mahasiswa. dikarenakan populasi 60 mahasiswa maka sampel yang akan diambil adalah keseluruhan dari populasi yaitu 
sebanyak 60 orang mahasiswa dari total keseluruhan populasi.

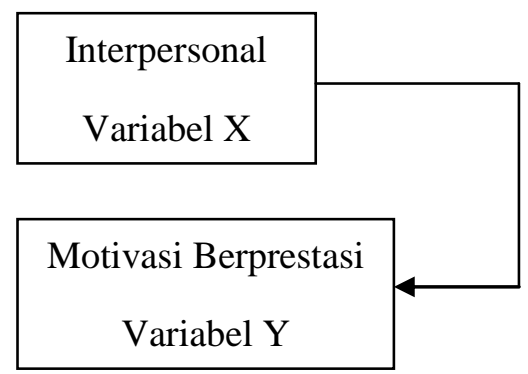

Dalam penelitian ini teknik sampling yang digunakan adalah teknik probability sampling. Dikarenakan jumlah populasi yang tidak terlalu banyak, yang hanya berjumlah 60 mahasiswa sehingga peneliti memutuska untuk mengambil seluruhnya menjadi sampel. Alat yang digunakan untuk mengumpulkan data primer dalam penelitian ini adalah kuesioner. Peneliti menggunakan kuesioner yang dikembangkan oleh Delgado dan Munuera (2005).

Uji hipotesis menggunakan SPSS 20.0 .Uji $\mathrm{T}$ varian yang berbeda (unequal variance) menggunakan rumus separated varians :

$$
\begin{aligned}
& \mathrm{t}=\frac{x 1-x 2}{\sqrt{\frac{s 1^{2}}{n 1}+\frac{s 2^{2}}{n 2}}} \\
& \text { dengan } \\
& \qquad s^{2}=\frac{(\mathrm{n} 1-1) \mathrm{s}_{1}{ }^{2}+(\mathrm{n} 2-1) \mathrm{s}_{2}{ }^{2}}{\mathrm{n} 1+\mathrm{n} 2-2}
\end{aligned}
$$

Keterangan :

$\mathrm{n}_{1} \quad$ : banyak siswa kelompok ekperimen

$\mathrm{n}_{2} \quad$ : banyak siswa kelompok kontrol

$\mathrm{x}_{1} \quad$ : nilai rata-rata kelompok eksperimen

$\mathrm{x}_{2} \quad$ : nilai rata-rata kelompok kontrol

$\mathrm{S}_{1}{ }^{2} \quad$ : varians kelompok eksperimen

$\mathrm{S}_{2}{ }^{2} \quad$ : varians kelompok kontrol

$S^{2} \quad$ : varians gabungan $S_{1}$ dan $S_{2}$

\section{HASIL DAN PEMBAHASAN}

Dari hasil penelitian yang didapat subjek yang berjenis perempuan berjumlah 50 orang dan laki laki 10 orang. Berdasarkan hasil deskripsi diketahui pengaruh hubungan interpersonal terhadap motivasi berprestasi pada mahasiswa PBSI STKIP Budidaya Binjai Stambuk 2017/2018 adalah P>0,005 yang mana terdapat penelitian pengaruh hubungan interpersonal terhadap motivasi berprestasi pada mahasiswa PBSI STKIP Budidaya Binjai. Penelitian adalah uraian tentang hal-hal yang berkaitan dengan proses kegiatan penelitian. Oleh karena itu isi laporan penelitian bukan hanya langkah-langkah yang telah dilakukan oleh peneliti saja. Hasil penelitian dilakukan untuk menguji hipotesis penelitian yang mana hipotesis penelitian adalah:

1) Ho : Tidak ada pengaruh yang tinggi atau rendah hubungan interpersonal terhadap motivasi berprestasi pada mahasiswa PBSI STKIP Budidaya Binjai.

2) Ha : ada pengaruh yang tinggi atau rendah hubungan interpersonal terhadap motivasi berprestasi pada mahasiswa PBSI STKIP Budidaya Binjai.

Analisis ini dengan cara mengkolerasikan masing-masing skor item dengan skor total. Dari hasil uji validasi skala hubungan interpersonal dari 40 skala yang di uji terdapat 10 item yang tidak valid artinya $\mathrm{P}<0,025$, sedangkan skala motivasi berprestasi dari 40 skala yang di uji terdapat 11 item yang tidak valid. Dalam pembahasan ini digunakan uji one sample kolmogrov-ssmirnov dengan menggunakan taraf signifikan 0,05. Data dinyatakan berdistribusi normal jika signifikan lebih besar dari $5 \%$ atau 0,05.Uji normalitas data menggunakan SPSS 20.0 . Nilai variabel hubungan interpersonal terdistribusi secara normal dengan nilai $\mathrm{p}>0,05(0,061>0,05)$. Dan berdasarkan tabel diatas dapat dilihat nilai variabel religiusitas terdistribusi secara normal dengan nilai $\mathrm{P}>0,05(0,372>0,05)$.

\section{SIMPULAN DAN SARAN}

\section{A. KESIMPULAN}

Berdasarkan hasil penelitian yang telah dilakukan, maka dapat disimpulkan bahwa ada hubungan yang sangat signifikan antara hubungan interpersonal dengan motivasi berprestasi, hal ini dibuktikan dengan nilai hasil koefisien korelasi yang menunjukan angka 0,330 dengan nilai sig 0,005 dimana $\mathrm{p}<0,05$. Artinya semakin tinggi hubungan interpersonal maka semakin baik motivasi berprestasi pada mahasiswa tersebut. Sebaliknya, semakin rendah hubungan 
interpersonal maka motivasi berprestasi pada mahasiswa semakin rendah.

\section{B. SARAN}

Berdasarkan temuan peneliti setelah melakukan penelitian dan menganalisis hasil penelitian, peneliti mengajukan beberapa saran terhadap pihak-pihak yang terkait, sebagai berikut:

\section{Bagi Subjek Penelitin}

Bagi mahasiswa PBSI STKIP Budidaya Binjai yang telah memiliki hubungan interpersonal yang tinggi agar dapat meningkatkan lagi motivasi berprestasi mereka dan tetap bersemangat dalam menyelesaikan tugas-tugas yang diberikan oleh pendidik.

\section{Kepada Dosen - dosen STKIP Budidaya Binjai}

Bagi dosen - dosen STKIP Budidaya Binjai agar dapat memberi mahasiswa support yang baik dalam proses pemebelajaran, dengan cara memberikan nasehat, arahan dan perhatian agar dapat meningkatkan motivasi berprestasi pada mahasiswa dan akan menjadikan mahasiswa selalu mahir dalam menyelesaikan masalah yang sedang dihadapi.

\section{Bagi Penelitian Selanjutnya}

Bagi penelitian selanjutnya yang tertarik meneliti tentang pengaruh hubungan interpersonal terhadap motivasi berprestasi pada mahasiswa PBSI diharapkan untuk mencari teori yang lebih baik dan baru terhadap kedua variabel penelitian ini, dan diharapkan juga untuk memperhatikan variabel lainnya yang memiliki hubungan yang lebih kuat dengan variabel yang hendak di teliti, serta dapat melakukan uji coba skala dengan jumlah item yang lebih banyak lagi, dengan responden berbeda dan jumlah responden yang lebih banyak sehingga tidak banyak item yang gugur, dan berikanlah pengarahan agar subjek mengisi skala yang disediakan sesuai dengan yang mereka alami.

\section{KEPUSTAKAAN}

Anwar Prabu Mangkunegara. Evaluasi Kinerja SDM. Bandung : Rafika Aditama. 2007.

AS, Enjang. Komunikasi Konseling. Bandung: Nuansa.2009.

Arikunto, Suharsimi. Prosedur Penelitian. Jakarta ;
Rineka Cipta. 2011.

Degeng, I.N.S. Paradigma Pendidikan Behavioristik ke Konstruktivistik. Malang: Bahan Presentasi Perkuliahan Prodi. TEP Pascasarjana Universitas negeri Malang. 2007.

Hafied Cangara. Pengantar Ilmu Kominukasi. Jakarta: PT. Raja Grafindo. 2001.

http://ekky-

psikologi08.blogspot.com/2010/10/18/hub ungan-interpersonal (diakses pada 18 Oktober 2010)

J, Rahkmat. Psikologi Komunikasi. Bandung: Remaja Rosdakarya. 2011.

Mulyana, Dedy. Ilmu Komunikasi Suatu Pengantar. Bandung: Remaja Rosdakarya. 2002.

Munandar. Peran Budaya Organisasi Dalam Peningkatan Unjuk Kerja Perusahaan, Jakarta: Bagian Psikologi Industri \& Organisasi Fakultas Psikologi Universitas Indonesia. 2010. 